\begin{tabular}{l}
\hline \hline GEOSPORT FOR SOCIETY \\
$\begin{array}{c}\text { GEOSPORT } \\
\text { SOCIETY }\end{array}$ \\
Scientific Journal founded in 2014 under aegis of University of Oradea (Romania), \\
University of Debrecen (Hungary), University of Gdánsk (Poland) \\
ISSN 2393-1353 \\
Edited by Oradea University Press \\
1, University Street, 410087, Oradea, Romania \\
Journal homepage: $h$ ttp://geosport.uoradea.ro/geosport.html
\end{tabular}

\title{
Association of Physical Activity (Sport) and Quality of Life: A Literature Review
}

\section{Sella DEVITA ${ }^{1 *}$, Anetta MÜLLER ${ }^{2}$}

1. University of Debrecen, Faculty of Public Health, Kassai str. 25/B, 4012, Debrecen, Hungary, e-mail: slldvt@gmail.com

2. University of Debrecen, Department of Sports Management, Böszörményi str. 138, 4032, Debrecen, Hungary, email: muller.anetta@econ.unideb.hu

* Corresponding author

Citation: Devita, S., \& Müller, A. (2020). Association of Physical Activity (Sport) and Quality of Life: A Literature Review. Geosport for Society, 12(1), 44-52. https://doi.org/10.30892/gss.1205-057

Article history: Received: 28.01.2020; Revised: 14.02.2020; Accepted: 23.03.2020, Available online: 25.03.2020

\begin{abstract}
Physical activity, especially in a form of sport, is known to improve life quality. Somehow studies comparing the effect of physical activity on quality of life in patients with health problems and healthy people are limited. The aim of this study is to provide an insight and evidence of association between physical activity and life quality in a group of people with health problems and a group of healthy people.
\end{abstract}

Keywords: physical activity, sport, life quality, healthy people, people with health problems

\section{Introduction}

Physical activity is highly correlated with improved well-being. It gives positive effects not only for physical health but also mental health. Furthermore, physical activity can improve functional performance and can be used as an intervention for the prevention and treatment of various diseases such as hypertension (Pereira et al., 1999; Hanashiro and Ceria-Ulep, 2011; Juhász et al., 2015), heart diseases (Newschaffer et al., 1998; Powell et al., 1987; Franco et al., 2005), diabetes (Ekelund et al., 2007; Apor, 2009; Baidog and Herman, 2018; Tătar et al., 2018; Papp et al., 2019), and bone problems like osteoporosis (Gregg et al., 2003). Moreover, exercise which is one type of physical activity, can have the same effect to antidepressant treatment which given for people with moderate or mild depression (Knapen et al., 2014). 
Health Organization (WHO) stated that around 3.2 million people died each year because of insufficient physical activity which results in the increase of the burden of global disease (Pratt et al., 2014; Ding et al., 2016; Gabnai et al., 2019). People with higher physical activity are known to have better life quality. Despite the fact that the benefit of physical activity to health is widely known somehow, the sedentary lifestyle still dominates the behavior and lifestyle especially in all generation (Müller et al., 2019; Biro et al., 2019; Laoues et al., 2019), especially young people population. The study by Kinmonth et al. (2008) showed intervention which facilitate the behavior change actually did not show more results compare to health promotion of physical activity given by using leaflet. There are other factors too that need to be considered like socioeconomic background and parents role in influencing lifestyle since people with higher socioeconomic background have more benefit in accesing sport service (Müller et al., 2019).

Besides the lack of motivation, the decline of physical activity also might be caused by certain health conditions. For example, people with respiratory health problems often feel reluctant to do physical exercise because of some factors like the decline of lung function and atrophy of leg muscles due to disuse, where they are struggled with exercise intolerance (Oga et al., 2003). Somehow it seems that improving physical activity in a long term could also be beneficial for people with respiratory problems like asthma and cronic obstructive pulmonary diseases (COPD) (Esteban et al., 2010; Müller et al., 2011; Müller et al., 2018).

Some studies investigated the correlation between these two variables, physical activity and quality of life, either in a population of elderly or young people (Rejeski and Mihalko, 2001; Bize et al., 2007; Dinyáné and Pusztai, 2016). Somehow studies comparing the effect of physical activity on quality of life in patients with health problems and its impact on the cost of illness are limited (Chomistek et al., 2013). So that re-examining the correlation between physical activity and life quality and the cost of illness in a group of people with health problems and a group of healthy people is essential. The main goal of this research is to provide an insight of association between physical activity (sport), and life quality. Also, the result of the study could be used as a reference for making guidelines related to physical activity (sport), to increase the quality of life and minimize the cost of illness. Furthermore, it can also be used as references for further studies.

\section{Methodology}

We searched for studies related to physical activity (sport), and life quality based on online journal databases including google scholar, Pubmed, and BMC with no restrictions on publication date so we can find comprehensive information. Search terms included the following: physical activity, sport, and life quality. 
Table 1. Physical activity and quality of life in a group of people with health problems

\begin{tabular}{|c|c|c|c|c|c|c|}
\hline 冚 & 范 & $\begin{array}{l}\frac{\tilde{N}}{\omega} \\
\frac{0}{0} \\
\frac{0}{\tilde{n}}\end{array}$ & 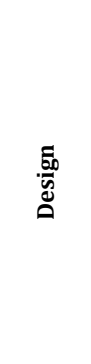 & 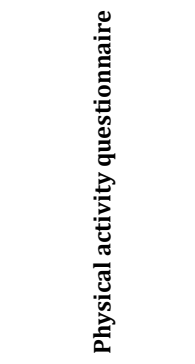 & 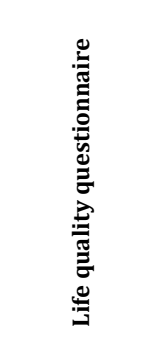 & 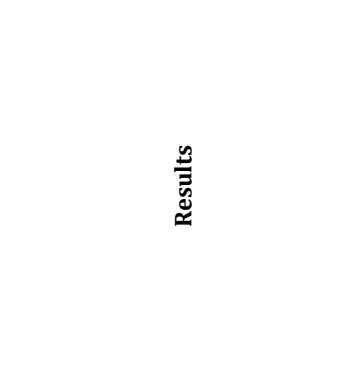 \\
\hline $\begin{array}{l}\text { Katayama et } \\
\text { al., } 2014\end{array}$ & $\begin{array}{l}\text { Chronic } \\
\text { hemodial } \\
\text { ysis } \\
\text { patients }\end{array}$ & $\begin{array}{l}31 \text { men } \\
\text { and } 17 \\
\text { women }\end{array}$ & $\begin{array}{l}\text { Cross } \\
\text { section } \\
\quad \text { al }\end{array}$ & Accelerometers & $\begin{array}{l}\text { EuroQol } \\
\text { questionnaire } \\
\text { (EQ-5D) }\end{array}$ & $\begin{array}{c}\text { In patients with non- } \\
\text { hemodialysis treatment days, life } \\
\text { quality is influenced by physical } \\
\text { activity more than } 4 \text { METs }\end{array}$ \\
\hline $\begin{array}{l}\text { Aidar et al., } \\
\text { (2011) }\end{array}$ & $\begin{array}{c}\text { Stroke } \\
\text { survivors }\end{array}$ & $\begin{array}{l}\text { Belo } \\
\text { Horizont } \\
\text { e (N=48) } \\
\text { Montes } \\
\text { Claros } \\
(\mathrm{N}=29) \\
\end{array}$ & $\begin{array}{l}\text { Cross } \\
\text { section } \\
\quad \text { al }\end{array}$ & $\begin{array}{l}\text { IPAQ short } \\
\text { version }\end{array}$ & SF-36 & $\begin{array}{l}\text { Active people have better score } \\
\text { of SF- } 36 \text { compared to people } \\
\text { with insufficient PA }\end{array}$ \\
\hline $\begin{array}{l}\text { Jepsen et al., } \\
2013\end{array}$ & $\begin{array}{c}\text { Obese } \\
\text { individua } \\
\text { ls } \\
\text { Western } \\
\text { Norway } \\
\end{array}$ & 49 & $\begin{array}{l}\text { Interve } \\
\text { ntion }\end{array}$ & Accelerometer & SF-36 & $\begin{array}{l}\text { PA has positive correlation to } \\
\text { physical functioning and life } \\
\text { satisfaction. Somehow no } \\
\text { association found between } \\
\text { mental health and PA }\end{array}$ \\
\hline $\begin{array}{l}\text { Rand et al., } \\
2010\end{array}$ & $\begin{array}{l}\text { Adults } \\
\text { with } \\
\text { chronic } \\
\text { stroke }\end{array}$ & 40 & $\begin{array}{l}\text { Cross } \\
\text { section } \\
\quad \text { al }\end{array}$ & $\begin{array}{c}\text { Self-report } \\
\text { questionnaire }\end{array}$ & SF-36 & $\begin{array}{l}\text { Association between PA and } \\
\text { mental health was not found. } \\
\text { Functional ability was related to } \\
\text { the amount of daily PA } \\
\text { performed. A number of daily PA } \\
\text { contribute to the physical score } \\
\text { of life quality independently. }\end{array}$ \\
\hline $\begin{array}{l}\text { Hebestreit et } \\
\text { al., } 2014\end{array}$ & $\begin{array}{c}\text { Cystic } \\
\text { fibrosis } \\
\text { (age } \geq 12 \\
\text { years, } \\
\text { FEV1 } \geq 35 \\
\% \text { ) } \\
\end{array}$ & 70 & $\begin{array}{l}\text { Interve } \\
\text { ntion }\end{array}$ & $\begin{array}{l}\text { Accelerometry \& } \\
\text { 7-day Physical } \\
\text { Activity Recall } \\
\text { Questionnaire }\end{array}$ & $\begin{array}{l}\text { German } \\
\text { version of } \\
\text { CFQ-R } \\
\text { questionnaire } \\
\text { for adults and } \\
\text { adolescent } \\
\end{array}$ & $\begin{array}{c}\text { Life quality was related with } \\
\text { physical fitness, specifically on } \\
\text { aerobic }\end{array}$ \\
\hline $\begin{array}{c}\text { Kallings et al., } \\
2007\end{array}$ & $\begin{array}{l}\text { Patient in } \\
\text { primary } \\
\text { health } \\
\text { care }\end{array}$ & 481 & Cohort & $\begin{array}{l}\text { Self-reported } \\
\text { exercise }\end{array}$ & $\begin{array}{c}\text { SF-36 } \\
\text { EuroQol EQ- } \\
5 \mathrm{D}\end{array}$ & $\begin{array}{c}\text { Prescription of physical activity } \\
\text { can be used as a treatment to } \\
\text { promote active lifestyle in } \\
\text { primary health care. }\end{array}$ \\
\hline $\begin{array}{c}\text { Deenik et al., } \\
2017\end{array}$ & $\begin{array}{c}\text { Inpatient } \\
\mathrm{s}\end{array}$ & 184 & $\begin{array}{l}\text { Cross } \\
\text { section } \\
\quad \text { al }\end{array}$ & $\begin{array}{c}\text { Accelerometer } \\
(\text { ActiGraph GTX+) }\end{array}$ & $\begin{array}{c}\text { EuroQol-5D } \\
\text { WHOQol-Bref }\end{array}$ & $\begin{array}{l}\text { Correlations were found between } \\
\text { physical activity and all domain } \\
\text { of life quality except character of } \\
\text { diseases, independent of patient, } \\
\text { and environmental domain. }\end{array}$ \\
\hline $\begin{array}{l}\text { Blom et al., } \\
2019\end{array}$ & $\begin{array}{l}\text { Attendee } \\
\text { of } \\
\text { primary } \\
\text { care in } \\
\text { Norway }\end{array}$ & 835 & $\begin{array}{l}\text { Cross } \\
\text { section } \\
\quad \text { al }\end{array}$ & $\begin{array}{c}\text { ActiGraph } \\
\text { accelerometer }\end{array}$ & SF-36 & $\begin{array}{l}\text { Light PA was positively related } \\
\text { with some domains of life quality } \\
\text { (role emotional, physical } \\
\text { functioning, vitality, role } \\
\text { physical, and general health) } \\
\text { while moderate and vigorous had } \\
\text { the same positive associations } \\
\text { but without role emotional. } \\
\text { Sedentary time found to have } \\
\text { negative correlation with life } \\
\text { quality in all dimensions }\end{array}$ \\
\hline
\end{tabular}


Table 2. Physical Activity and Quality of Life in a Group of Healthy People

\begin{tabular}{|c|c|c|c|c|c|c|}
\hline 宔 & $\frac{0}{\text { हूँ }}$ & $\begin{array}{l}\frac{\tilde{N}}{\mathrm{n}} \\
\frac{0}{\tilde{\Xi}} \\
\text { हूँ }\end{array}$ & 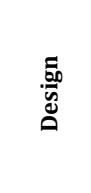 & 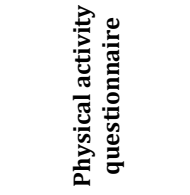 & 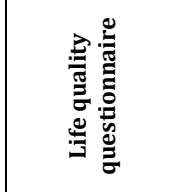 & $\frac{\mathscr{n}}{\vec{\Xi}}$ \\
\hline $\begin{array}{l}\text { Acree et al., } \\
\quad 2006\end{array}$ & $\begin{array}{l}\text { Healthy } \\
\text { older adults }\end{array}$ & 112 & $\begin{array}{l}\text { Cross } \\
\text { section } \\
\quad \text { al }\end{array}$ & $\begin{array}{c}\text { Johnson Space } \\
\text { Center } \\
\text { physical } \\
\text { activity scale }\end{array}$ & SF-36 & $\begin{array}{l}\text { Life quality was increased in all } \\
\text { domains for the group who } \\
\text { performed more physical activity, } \\
\text { specifically bodily pain, vitality, } \\
\text { physical functioning, role-physical, } \\
\text { social functioning }\end{array}$ \\
\hline $\begin{array}{c}\text { Shibata et al., } \\
2007\end{array}$ & $\begin{array}{l}\text { Japanese } \\
\text { adults }\end{array}$ & 1,211 & $\begin{array}{l}\text { Cross } \\
\text { section } \\
\text { al }\end{array}$ & $\begin{array}{l}\text { IPAQ short } \\
\text { version }\end{array}$ & SF-8 & $\begin{array}{l}\text { People who performed PA based on } \\
\text { the recommendation had better life } \\
\text { quality on some dimensions. }\end{array}$ \\
\hline $\begin{array}{l}\text { Balboa-Castillo } \\
\text { et al., } 2011\end{array}$ & $\begin{array}{l}\text { People aged } \\
62 \text { and over }\end{array}$ & 1,097 & Cohort & $\begin{array}{c}\text { PA } \\
\text { questionnaire } \\
\text { used in the } \\
\text { Nurses' Health } \\
\text { Study and the } \\
\text { Health } \\
\text { Professionals' } \\
\text { Follow-up } \\
\text { Study }\end{array}$ & SF-36 & $\begin{array}{l}\text { People who performed light PA in the } \\
\text { upper quantile had better scores of } \\
\text { SF-36 in the domain of mental health, } \\
\text { bodily pain, vitality, linear trend, } \\
\text { physical role, linear trendsocial } \\
\text { functioning, emotional role } \\
\text { and physical functioning }\end{array}$ \\
\hline $\begin{array}{c}\text { Omorou et al., } \\
2013\end{array}$ & French adult & 4,909 & $\begin{array}{l}\text { Cross- } \\
\text { section } \\
\text { al data }\end{array}$ & $\begin{array}{l}\text { IPAQ short } \\
\text { version }\end{array}$ & $\begin{array}{c}\text { WHOQOL- } \\
\text { BREF }\end{array}$ & $\begin{array}{l}\text { Higher positive correlation was found } \\
\text { between sport and life quality for } \\
\text { people who performed high and low } \\
\text { PA compare to people who did } \\
\text { moderate PA. Dose-response } \\
\text { association was found between social } \\
\text { relationships and psychological } \\
\text { health in women group }\end{array}$ \\
\hline $\begin{array}{c}\text { Anokye, et al, } \\
2012\end{array}$ & $\begin{array}{l}40-60 \text { years } \\
\text { old }\end{array}$ & 5,537 & $\begin{array}{l}\text { Cross- } \\
\text { section } \\
\text { al data }\end{array}$ & $\begin{array}{l}\text { Accelerometer \& } \\
\text { Questionnaire } \\
\text { related to sports } \\
\text { and exercise, } \\
\text { housework, } \\
\text { walking, and } \\
\text { occupational } \\
\text { activity } \\
\end{array}$ & EQ-5D & $\begin{array}{c}\text { People who performed higher levels } \\
\text { of PA had better quality of life. Even } \\
\text { better life quality was shown in the } \\
\text { obejctive measurement of PA } \\
\text { compared to subjective } \\
\text { measurement. }\end{array}$ \\
\hline $\begin{array}{l}\text { Motamed-Gorji } \\
\text { et al., } 2019\end{array}$ & Students & 23,043 & $\begin{array}{l}\text { Cross } \\
\text { section } \\
\quad \text { al }\end{array}$ & $\begin{array}{c}\text { Physical } \\
\text { Activity } \\
\text { Questionnaire } \\
\text { for } \\
\text { Adolescents } \\
\text { (PAQ-A) } \\
\end{array}$ & $\begin{array}{l}\text { Adolescent Core } \\
\text { version of the } \\
\text { Pediatric } \\
\text { Quality of Life } \\
\text { (PedsQL) }\end{array}$ & $\begin{array}{c}\text { Significant correlation was found } \\
\text { between total score of life quality and } \\
\text { PA while sedentary time associated } \\
\text { with lower score of life quality. }\end{array}$ \\
\hline $\begin{array}{c}\text { Nowak et al., } \\
2019\end{array}$ & $\begin{array}{l}\text { University } \\
\text { students }\end{array}$ & 595 & $\begin{array}{l}\text { Cross } \\
\text { section } \\
\quad \text { al }\end{array}$ & $\begin{array}{l}\text { IPAQ long } \\
\text { version }\end{array}$ & $\begin{array}{l}\text { Comprehensive } \\
\text { Quality of Life } \\
\text { Scale-Adult } \\
\text { (ComQol-A5) }\end{array}$ & $\begin{array}{l}\text { Household physical activity had more } \\
\text { positive correlation to life quality. } \\
\text { Negative relation was found between } \\
\text { subjective and objective life quality } \\
\text { and sedentary behavior at the } \\
\text { weekend while sedentary during the } \\
\text { week had positive relation with } \\
\text { subjective life quality. }\end{array}$ \\
\hline $\begin{array}{l}\text { Chang et al., } \\
2019\end{array}$ & $\begin{array}{l}\text { Taiwanese } \\
\text { adults }\end{array}$ & 6182 & Cohort & $\begin{array}{l}2008 \text { Physical } \\
\text { Activity } \\
\text { Guidelines for } \\
\text { Americans } \\
\text { (PAGA) }\end{array}$ & SF-36 & $\begin{array}{c}\text { Positive dose-response effects was } \\
\text { found between life quality on the } \\
\text { physical domain and regular exercise. } \\
\text { More positive effects on life quality } \\
\text { on mental domain was related with } \\
\text { regular exercise. While irregular } \\
\text { exercise improve life quality on } \\
\text { mental and physical domain }\end{array}$ \\
\hline
\end{tabular}


We also used manual search from bibliographies of the articles we identified before. The inclusion criteria for this study are: the article was written in the English language, the study focused on physical activity (sport) in relation with quality of life. Cross-sectional studies, prospective cohort studies were considered for inclusion. Studies were excluded if they did not focus specifically on physical activity (sport) and quality of life. Protocol, secondary research, editorial articles, and studies with intervention were excluded as well.

The search identified 16 studies that fulfill the selection criteria which listed in the table 1 with detailed in the year and characteristics of the sample and methodology used in the studies. Most studies used cross-sectional design $(n=11)$. Three studies used cohort design and two studies used interventions.

Instruments used to measure physical activity a accelerometer, Active Australia Survey, IPAQ, short form ipaq, physical activity scale of Johnson Space Center, 7-day Physical Activity Recall Questionnaire. Rand et al. (2010) used two kind of physical measurements accelerometer for objective measure and self -report questionnaire for subjective measure named PA Scale for Individuals with Physical Disabilities (PASIPD). Study by Balboa-Castillo et al. (2011) using spanish version of PA questionnaire that had been used and validated before in the Nurses' Health Study and the Health Professionals' Follow-up Study.

\section{Discussion}

From 16 studies on the review we identified seven instruments used to measure life quality. Those are EuroQol questionnaire (EQ-5D), SF-36, SF-8, World Health Organization Quality of Life Questionnaire abbreviated version (WHOQol-Bref), CFQ-R questionnaire, Adolescent Core version of the Pediatric Quality of Life (PedsQL), and Comprehensive Quality of Life Scale-Adult (ComQol-A5). SF 8 is abbreviated version of SF 36. Most of the studies used SF-36 scale. It has eight domain: physical functioning $(\mathrm{PF})$, social functioning (SF), role physical (RP), role emotional (RE), bodily pain (BP), mental health $(\mathrm{MH})$, general health $(\mathrm{GH})$, vitality (VT).

Studies showed associations between physical activity (PA) level and quality of life (QOL). That higher PA resulted in a higher quality of life (Aidar et al., 2011; Shibata et al., 2007). Hebestreit et al. (2014) explained in more detail that life quality related to health was associated with aerobic exercise or sport (Omorou et al., 2013). While the study by Nowak et al. (2019) said it is the physical activity in the household, which was most positively correlated to the quality of life.

Physically active participants had higher life quality on physical functioning domain (Aidar et al., 2011; Acree et al., 2006; Jepsen et al., 2013; Rand et al., 2010), mental health (Chang et al., 2019), role-physical, vitality, social functioning, and bodily 
pain (Acree et al., 2006). Different with studies by Jepsen et al (2013) and Rand at al (2010) that said no association between mental health and PA. While performing less frequent PA showed moderate reduction in psychological stress (Hamer et al., 2008). It seems physical exercise might have positive effect on mental health, however, the evidence base for it is limited (Biddle and Asare, 2011). Mindfulness however has positive impact on physical performance (Blaire-Resnick, 2015), physical health (Murphy et al., 2012) and mental health (Prazak et al., 2012), hence its integration into curriculums is highly recommended (Lengyel, 2017; Lengyel et al., 2019a; Lengyel et al., 2019b). PA was not related with the environmental domain, independent of patient and disease characteristics (Deenik et al., 2017). In contrast with physically active time; sedentary time is known to be causing a negative impact. Sedentary time duration had a significant inverse association with total QoL (Motamed-Gorji et al., 2019). More specifically, time spent sedentary was negatively associated with physical functioning, general health, vitality, social functioning and mental health (Blom et al., 2019) while Nowak et al. (2019) explained that sedentary behaviour at the weekends was negatively related to objective and subjective quality of life but sedentary behaviour during the week related positively with the subjective quality of life.

Insufficiently active is defined as physically involved in moderate-intensity activity or activities for minimum ten continuous minutes per week but do not meet active classification which defined as equal or more than 150 minutes per week of moderate intensity activity (Carlson et al., 2015). Physical activity recommendation guideline used in study by Shibata et al (2007) was 23 METS per hour per week for adult. Somehow it could be varied based on individual conditions. This prescription of PA, can be a proper treatment in primary health care settings (Kallings et al., 2007). Even for people with health problems, physical activity still gave positive effect to life quality (Aidar et al., 2011; Blom et al., 2019; Deenik et al., 2017; Jepsen et al., 2013; Hebestreit et al., 2014; Kallings et al., 2007; Katayama et al., 2014; Rand et al., 2010).

\section{Conclusions}

Physical activity improves people's life quality in general. Some domains of quality of life that improved could be varied. Mental health as one domain of quality of life, in some studies related to physical activity but some studies did not show association between these two variables. Somehow doing physical activity as recommended which defined as moderate intensity of PA for 150 minutes per week or more, evident to improve life quality for all groups, including people with health problems. There are some limitations of this study. First the literature limited to english only. Bias in concluding the result could be affected by the difference of instruments used to measure variables. The strength of this study is that we searched in the online database without constriction of published years to have more comprehensive results. 


\section{Acknowledgement}

The publication is supported by the GINOP-2.3.2-15-2016-00005 project. The project is co-financed by the European Union under the European Regional Development Fund.

\section{References}

Acree, L. S., Longfors, J., Fjeldstad, A. S., Fjeldstad, C., Schank, B., Nickel, K. J., ... \& Gardner, A. W. (2006). Physical activity is related to quality of life in older adults. Health and quality of life outcomes, 4(1), 37.

Aidar, F. J., de Oliveira, R. J., Silva, A. J., de Matos, D. G., Carneiro, A. L., Garrido, N., ... \& Reis, V. M. (2011). The influence of the level of physical activity and human development in the quality of life in survivors of stroke. Health and quality of life outcomes, 9(1), 89.

Anokye, N. K., Trueman, P., Green, C., Pavey, T. G., \& Taylor, R. S. (2012). Physical activity and health related quality of life. BMC public health, 12(1), 624.

Apor, P. (2009). Physical activity in prevention and treatment of diabetes. Weekly Medicine, 150(13), 579-587.

Baidog, A., \& Herman, G.V. (2018). The Influence of Sports and Physical Activity on the Metabolic Syndrome: A Systematic Review. Analele Universităţii din Oradea. Fascicula Educaţie Fizică şi Sport, 28(1), 39-45.

Balboa-Castillo, T., León-Muñoz, L. M., Graciani, A., Rodríguez-Artalejo, F., \& Guallar-Castillón, P. (2011). Longitudinal association of physical activity and sedentary behavior during leisure time with health-related quality of life in community-dwelling older adults. Health and Quality of Life Outcomes, 9(1), 47.

Biddle, S. J. H., \& Asare, M. (2011). Physical activity and mental health in children and adolescents: a review of reviews. British Journal of Sports Medicine, 45(11), 886-895.

Biró, M., Tatár, A., Pucsok, J. M., Lenténé, P. A., Mikhárdi, S., Hidvégi, P. \& Molnár, A. (2019a). The Health Tourism trends in the North Great Plain Hotels in Hungary. In: Balogh, László (ed.) Multifaced Sports Science, Debrecen, Magyarország: University of Debreceni Sports Scientific Coordination Institute, pp. 9-20, 12 p.

Bize, R., Johnson, J. A., \& Plotnikoff, R. C. (2007). Physical activity level and health-related quality of life in the general adult population: A systematic review. Preventive Medicine, 45(6), 401-415.

Blair Kennedy, A., \& Resnick, P. B. (2015). Mindfulness and physical activity. American Journal of Lifestyle Medicine, 9(3), 221-223.

Blom, E. E., Aadland, E., Skrove, G. K., Solbraa, A. K., \& Oldervoll, L. M. (2019). Health-related quality of life and intensity-specific physical activity in high-risk adults attending a behavior change service within primary care. PLOS ONE, 14(12), e0226613.

Carlson, S. A., Fulton, J. E., Pratt, M., Yang, Z., \& Adams, E. K. (2015). Inadequate Physical Activity and Health Care Expenditures in the United States. Progress in Cardiovascular Diseases, 57(4), 315-323.

Chang, H.-C., Liang, J., Hsu, H.-C., Lin, S.-K., Chang, T.-H., \& Liu, S.-H. (2019). Regular exercise and the trajectory of health-related quality of life among Taiwanese adults: a cohort study analysis 20062014. BMC Public Health, 19(1), 1352.

Chomistek, A. K., Manson, J. E., Stefanick, M. L., Lu, B., Sands-Lincoln, M., Going, S. B., ... Eaton, C. B. (2013). Relationship of Sedentary Behavior and Physical Activity to Incident Cardiovascular Disease. Journal of the American College of Cardiology, 61(23), 2346-2354.

Deenik, J., Kruisdijk, F., Tenback, D., Braakman-Jansen, A., Taal, E., Hopman-Rock, M., ... van Harten, P. (2017). Physical activity and quality of life in long-term hospitalized patients with severe mental illness: a cross-sectional study. BMC Psychiatry, 17(1), 298.

Ding, D., Lawson, K. D., Kolbe-Alexander, T. L., Finkelstein, E. A., Katzmarzyk, P. T., van Mechelen, W., \& Pratt, M. (2016). The economic burden of physical inactivity: a global analysis of major noncommunicable diseases. The Lancet, 388(10051), 1311-1324.

Dinyáné, M. S., \& Pusztai, G. (2016). Use of the short (5-item) version of the WHO well-being questionnaire in first year students of Semmelweis University. Orvosi hetilap, 157(44), 1762-1768. 
Ekelund, U., Griffin, S. J., \& Wareham, N. J. (2007). Physical Activity and Metabolic Risk in Individuals With a Family History of Type 2 Diabetes. Diabetes Care, 30(2), 337-342.

Esteban, C., Quintana, J. M., Aburto, M., Moraza, J., Egurrola, M., Perez-Izquierdo, J., ... Capelastegui, A. (2010). Impact of changes in physical activity on health-related quality of life among patients with COPD. European Respiratory Journal, 36(2), 292-300.

Franco, O. H., de Laet, C., Peeters, A., Jonker, J., Mackenbach, J., \& Nusselder, W. (2005). Effects of physical activity on life expectancy with cardiovascular disease. Archives of internal medicine, 165(20), 2355-2360.

Gabnai, Z., Müller, A., Bács, Z., Bácsné, B.É. (2019). The economic burden of physical inactivity at national level. Health Development Journal, 60(1), 20-30.

Gregg, E. W., Cauley, J. A., Stone, K., Thompson, T. J., Bauer, D. C., Cummings, S. R., ... \& Study of Osteoporotic Fractures Research Group. (2003). Relationship of changes in physical activity and mortality among older women. Jama, 289(18), 2379-2386.

Hamer, M., Stamatakis, E., \& Steptoe, A. (2008). Dose-response relationship between physical activity and mental health: the Scottish Health Survey. British Journal of Sports Medicine, 43(14), 1111-1114.

Hanashiro, V., \& Ceria-Ulep, C. D. (2011). Native Hawaiians and Physical Activity. Issues in Mental Health Nursing, 32(10), 664-666.

Hebestreit, H., Schmid, K., Kieser, S., Junge, S., Ballmann, M., Roth, K., ... Kriemler, S. (2014). Quality of life is associated with physical activity and fitness in cystic fibrosis. BMC Pulmonary Medicine, 14(1), 26.

Jepsen, R., Aadland, E., Andersen, J. R., \& Natvig, G. K. (2013). Associations between physical activity and quality of life outcomes in adults with severe obesity: a cross-sectional study prior to the beginning of a lifestyle intervention. Health and Quality of Life Outcomes, 11(1), 187.

Juhász, I., Kopkáné, P. J., Kiszela, K., Bíró, M., Müller, A., Révész, L. (2015). Effect of recreational physical activity of the elderly on the cardiorespiratory system. Hungarian Review of Sport Science, 16(63) 4-8.

Kallings, L. V., Leijon, M., Hellénius, M.-L., \& Ståhle, A. (2007). Physical activity on prescription in primary health care: a follow-up of physical activity level and quality of life. Scandinavian Journal of Medicine \& Science in Sports, 18(2), 154-161.

Katayama, A., Miyatake, N., Nishi, H., Uzike, K., Sakano, N., Hashimoto, H., \& Koumoto, K. (2014). Evaluation of physical activity and its relationship to health-related quality of life in patients on chronic hemodialysis. Environmental Health and Preventive Medicine, 19(3), 220-225.

Kinmonth, A.-L., Wareham, N. J., Hardeman, W., Sutton, S., Prevost, A. T., Fanshawe, T., ... Griffin, S. J. (2008). Efficacy of a theory-based behavioural intervention to increase physical activity in an atrisk group in primary care (ProActive UK): a randomised trial. The Lancet, 371(9606), 41-48.

Knapen, J., Vancampfort, D., Moriën, Y., \& Marchal, Y. (2014). Exercise therapy improves both mental and physical health in patients with major depression. Disability and Rehabilitation, 37(16), 1490-1495.

Laoues, C.N., Müller, A., Mezo, K., Mercs, E., Molnár, A. (2019). Research Of The Value Preferences Of Environmental Education And Healthy Life In Parents Of Children Who Go To Green And Non-Green Kindergarten. Acta Carolus Robertus, 9(2), 89-109.

Lengyel, A. (2017). Pilot testing of the Attention and Awareness Mindfulness Scale (AAMS): testing alternative solutions to certain methodological issues. Journal of Mental Health and Psychosomatics, 18(4), 334-364.

Lengyel, A., Kovács, S., Müller, A., Dávid, L., Szőke, S., \& Bácsné Bába, É. (2019b). Sustainability and Subjective Well-Being: How Students Weigh Dimensions. Sustainability, 11(23), 6627.

Lengyel, A., Szőke, S., Kovács, S., Dávid, L. D., Baba, E. B., \& Müller, A. (2019a). Assessing the essential pre-conditions of an authentic sustainability curriculum. International Journal of Sustainability in Higher Education.

Motamed-Gorji, N., Qorbani, M., Nikkho, F., Asadi, M., Motlagh, M. E., Safari, O., ... Kelishadi, R. (2019). Association of screen time and physical activity with health-related quality of life in Iranian children and adolescents. Health and Quality of Life Outcomes, 17(1), 2.

Müller, A., Balatoni, I., Csernoch, L., Bács, Z., Bíró, M., Bendíková, E., ... \& Bácsné, É. B. (2018). Quality of life of asthmatic patients after complex rehabilitation treatment. Orvosi hetilap, 159(27), 1103-1112.

Müller, A., Bendíková, E., Herpainé, L.J.; Bácsné, B.É., Łubkowska, W., Mroczek, B. (2019). Survey of regular physical activity and socioeconomic status in Hungarian preschool children. Family Medicine And Primary Care Review, 21(3), 237-242. 
Müller, A., Kerényi, E., Könyves, E. (2011). Effect of climate therapy and rehabilitation in Mátra Medical Institute Applied Studies in Agribusiness and Commerce. Abstract-Applied Studies In Agribusiness And Commerce, 5(3-4), 39-42.

Murphy, M. J., Mermelstein, L. C., Edwards, K. M., \& Gidycz, C. A. (2012). The benefits of dispositional mindfulness in physical health: a longitudinal study of female college students. Journal of American College Health, 60(5), 341-348

Newschaffer, C.J., Brownson, C.A., \& Dusenbury, L.J. (2003). Cardiovascular disease. Chronic Disease Epidemiology and Control, $2^{\text {nd }}$ edition., Published by American Public Health Association.

Nowak, P. F., Bożek, A., \& Blukacz, M. (2019). Physical Activity, Sedentary Behavior, and Quality of Life among University Students. BioMed Research International, 1-10.

Oga, T., Nishimura, K., Tsukino, M., Sato, S., \& Hajiro, T. (2003). Analysis of the Factors Related to Mortality in Chronic Obstructive Pulmonary Disease. American Journal of Respiratory and Critical Care Medicine, 167(4), 544-549.

Omorou, Y. A., Erpelding, M.-L., Escalon, H., \& Vuillemin, A. (2013). Contribution of taking part in sport to the association between physical activity and quality of life. Quality of Life Research, 22(8), 2021-2029.

Papp, B.M., Șerbescu, C., Caciora, T., Baidog, A., Varodi, M.O. (2019). The Effects of a Physical Activity Program on Body Composition and Physical Condition in the Overweight Adult. Analele Universităţii din Oradea. Fascicula Educaţie Fizică şi Sport, 29(1), 1-9.

Pereira, M. A., Folsom, A. R., McGovern, P. G., Carpenter, M., Arnett, D. K., Liao, D., ... Hutchinson, R. G. (1999). Physical Activity and Incident Hypertension in Black and White Adults: The Atherosclerosis Risk in Communities Study. Preventive Medicine, 28(3), 304-312.

Powell, K. E., Thompson, P. D., Caspersen, C. J., \& Kendrick, J. S. (1987). Physical Activity and the Incidence of Coronary Heart Disease. Annual Review of Public Health, 8(1), 253-287.

Pratt, M., Norris, J., Lobelo, F., Roux, L., \& Wang, G. (2014). The cost of physical inactivity: moving into the $21^{\text {st }}$ century. British journal of sports medicine, 48(3), 171-173.

Prazak, M., Critelli, J., Martin, L., Miranda, V., Purdum, M., \& Powers, C. (2012). Mindfulness and its role in physical and psychological health. Applied Psychology: Health and Well-Being, 4(1), 91-105.

Rand, D., Eng, J. J., Tang, P.-F., Hung, C., \& Jeng, J.-S. (2010). Daily physical activity and its contribution to the health-related quality of life of ambulatory individuals with chronic stroke. Health and Quality of Life Outcomes, 8(1), 80.

Rejeski, W. J., \& Mihalko, S. L. (2001). Physical Activity and Quality of Life in Older Adults. The Journals of Gerontology Series A: Biological Sciences and Medical Sciences, 56(Supplement 2), 23-35.

Shibata, A., Oka, K., Nakamura, Y., \& Muraoka, I. (2007). Recommended level of physical activity and health-related quality of life among Japanese adults. Health and Quality of Life Outcomes, 5(1), 64.

Tătar, C.F., Herman, G. V., \& Pețan, P. (2018). Sport and physical activity engagement in Romania. Geosport for Society, 8(1), 40-50. 